\title{
Exploratory Model of the Impact of Agriculture on Nigerian Economy
}

\author{
Okeke, Evelyn Nkiruka \\ Department of Mathematics \& Statistics, Federal \\ University Wukari, Taraba State, Nigeria
}

\section{ABSTRACT}

This paper explored four models in determining the impact of four agricultural sub-sectors of on the Nigerian GDP. The data is on the contribution of four different sub-sectors of agriculture on Nigerian Economy and was obtained from Central Bank of Nigeria statistical bulletin. The findings revealed that ridge regression and PCR are good regression estimation methods for predicting GDP. From the models there is strong indication that fish production in Nigeria is too insufficient to sustain her ever increasing population and improve her economy. Also, the ever increasing demand for fish by Nigerians due to high cost of meat in the market is clearly shown in the models and this stands to say that a lot need to be done to improve fish production in Nigeria to ensure sustainable growth and development.

KEYWORD : Gross Domestic Product (GDP), Agriculture, Economy, Crop production, Livestock production, Fishery, Forestry, Multicollinearity, Ridge regression, PCR, Adjusted R-squared, Standard error of the estimate

\section{Introduction}

Agriculture is the process of producing food, feed, fiber, fuel, medicinal plants and other goods by cultivation and breeding of plants and animals. One of the critical sectors that deserve attention in any country's economy, especially the developing countries such as Nigeria, is agricultural sector. Agriculture in Nigeria is a branch of the economy in Nigeria that provides employment for about $30 \%$ of the population as of 2010 (Wikipedia).

Nigeria's agricultural development policy over the years has been formed by the belief that the development of agriculture is a sine-qua-non for the overall growth and development of the economy. Agricultural development efforts have been to enhance and sustain the capacity of the sector in order to ensure growth with emphasis on the attainment of a sustainable level in the production of basic food commodities, especially those in which the country

\author{
Okeke, Joseph Uchenna \\ Department of Mathematics \& Statistics, Federal \\ University Wukari, Taraba State, Nigeria
}

has comparative advantage. It also involve developing the capacity to increase the production of agricultural raw material to meet the growing needs of an expanding industrial sector, as well as the production and processing of the exportable cash crop to boost the nation's non-oil foreign exchange capacity. Agricultural sector is seen as an engine that contributes to the growth of the overall economy of Nigeria. Despite this, the sector is still characterized with low input, limited areas under cultivation, poor agricultural machinery, and low input, which are caused by government overdependence on monocultural economy based on oil sector.

Many researchers have statistically analyzed the contribution of agricultural sector on economic growth of Nigeria. Sertoglu et al (2017) empirically examines the impact of agricultural sector on the economic growth of Nigeria, using time series from 1981 to 2013 and discovered that Real Gross Domestic Product (RGDP), agricultural output and oil rents have a long-run equilibrium relationship. They recommended that Government and policy makers should embark on diversification and enhance more allocation in terms of budgeting to the agricultural sector.

Izuchukwu (2011) analyzed the contribution of agricultural sector on the Nigerian economic development using panel data sources from the statistical bulletin of the Central Bank of Nigeria and World Bank's development indicators and discovered a positive relationship between Gross Domestic Product vis-a-vis domestic saving, government expenditure on agricultural and foreign direct investment between the period of 1966-2007. This paper aimed at determining the impact of crops, livestock, fisheries, and forestry sub-sectors on the economic growth and development of Nigeria.

\section{Agriculture and Nigerian Economy}

Noko (2017) stated that agriculture is estimated to be the largest contributor to the non-oil foreign exchange. According to him a strong agricultural sector is essential to economy development both in its own rights and to simulate and support the growth of 
industries. Economy growth has gone hand in hand with agricultural progress; stagflation in agriculture is the principal explanation for poor economy performance, while rising agricultural activities has been the most concomitant of successful industrialization (Ukeje 1999). The labour-intensive character of the sector reduces its contribution to the GDP; Noko lamented, and still maintained that agricultural exports are a major earner of foreign exchange in Nigeria.

In an effort to increase the agricultural production in Nigeria, this year, 2017, the Central Bank of Nigeria has approved the disbursement of about \#75 billion as loan to farmers in the 36 states and the Federal Capital Territory (FCT) under the Nigerian Incentive-Based Risk Sharing in Agricultural Lending (NIRSAL). The loan guarantee scheme is a public-private sector initiative set up to transform the country's agricultural sector. It was initiated by the Apex bank, the Banker's Committee and the Federal Ministry of Agriculture and rural Development, to guarantee $75 \%$ loans provided by Deposit Money Banks to farmers as part of effort to transform the countries agricultural sector (Uzonwanne 2017)

Gollin et al (2004) emphasized that low agricultural productivity can substantially delay industrialization. According to them improvement in the agricultural productivity can hasten the start of industrialization and hence have large effects on a country's relative income. It provides employment opportunities for the teeming population, eradicates poverty and contributes to the growth to the economy.

Ukeji (2003) submitted that in the 1960's agriculture contributed up to $64 \%$ to the nation's total GDP but it gradually declined to $48 \%$ in 1970 's and it continued in 1980 to $20 \%$, and $19 \%$ in 1985 which was as a result of oil glut of the 1980's. Historically, the root of the crisis in Nigeria economy lies in the neglects of the agricultural sector by the Federal Government of Nigeria due to oil sector.

The GDP from agriculture decreased to 4,662,010.12 NGN million in the fourth quarter of 2016 from $5,035,069.07$ NGN millions in the third quarter of 2016. GDP from agriculture in Nigeria averaged 369,673.12NGN million from 2010 until 2016, reaching an all time high of 5,035,069.07NGN in the third quarter of 2016 and a record low of $2,594,759.86 \mathrm{NGN}$ million in the first quarter of 2010 (CBN 2014). Below is the Table showing the GDP from Agriculture and other sources

\section{Table 1: Distribution of Last and Previous Quarter of 2013 GDP from Agriculture and Others}

\begin{tabular}{|c|c|c|}
\hline GDP & $\begin{array}{c}\text { Last Quarter } \\
\text { of 2013 }\end{array}$ & $\begin{array}{c}\text { Previous } \\
\text { Quarter }\end{array}$ \\
\hline Agriculture & $4,662,010.12$ & $\mathbf{5 , 0 3 5 , 0 6 9 . 0 7}$ \\
\hline Construction & $623,349.23$ & $\mathbf{5 4 3 , 8 0 8 . 1 2}$ \\
\hline Manufacturing & $1,645,401.74$ & $\mathbf{1 , 6 1 4 , 8 9 4 . 6 5}$ \\
\hline Mining & $2,041,492.97$ & $\mathbf{1 , 6 2 4 , 0 1 8 . 0 1}$ \\
\hline $\begin{array}{c}\text { Public } \\
\text { Administration }\end{array}$ & $430,861.50$ & $\mathbf{3 7 1 , 7 3 1 . 3 3}$ \\
\hline Services & $6,977,150.10$ & $\mathbf{6 , 0 3 5 , 6 5 0 . 6 2}$ \\
\hline Transport & $217,313.24$ & $\mathbf{2 1 0 , 9 7 2 . 6 6}$ \\
\hline Utilities & $\mathbf{1 1 1 , 8 0 1 . 0 6}$ & $\mathbf{8 5 , 4 3 2 . 6 8}$ \\
\hline
\end{tabular}

Source: National Bureau of Statistics

Fig 1: Last and Previous Quarter of 2016 GDP from Agriculture and Others

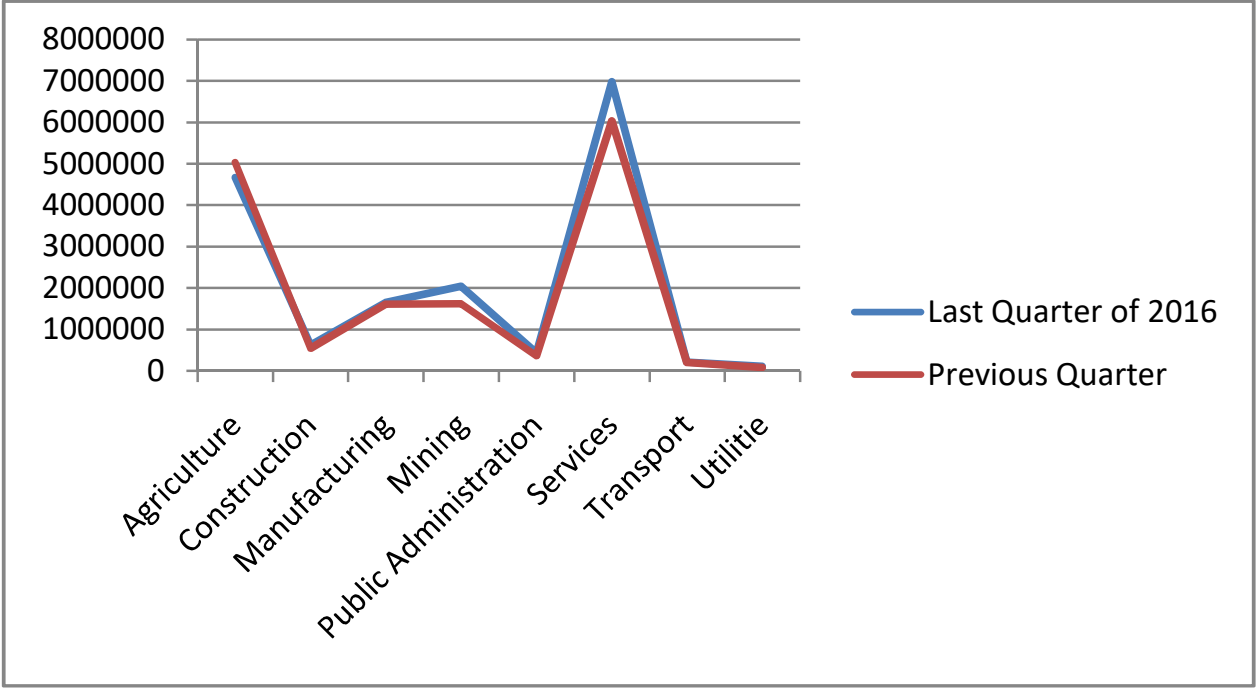


In 1990, policy measures were initialized and strategies designed to propel agricultural development targeting the year 2010. Emphasis was on food, livestock, the fisheries and the forestry.

Food crops constitute the largest component of crops sub-sector of Nigeria's agricultural sector. They are categorized broadly into cereals, roots, tubers, plantain, oil seeds and nuts, pulses, vegetables and fruits, sugar and beverages.

For the purpose of planning of self-sufficiency in livestock production, output in the sector has been categorized into short and long term. Livestock whose sufficiency level could be conveniently attained within five years such as beef, poultry products, goat meat, mutton, and pork were classified as short term while those that would at least in 15 years be sufficient were categorized as long term.

Forestry concern is on the preservation and maintenance of economic trees and plants. It also involves the eradication of various forms of resources associated with forest. Agriculturists derived a lot from such plants preserved and they include: timber for plywood, furniture, houses and boats, manufacturing of papers, electric poles etc.

Fishing sub-sector involves breeding and catching fishes from the rivers for human consumption. Fishing constitutes major occupation of river line people. Fish constitute main sources of protein. Ezeokoli (2011)

\section{Data and its Presentation}

The data used for this work is mainly secondary data, sourced from the Central Bank of Nigeria statistical bulletin (2014) via: annual report and statement of account. Information on the annual GDP from agricultural sub-sector: food crop production $\left(X_{1}\right)$, livestock production $\left(X_{2}\right)$, forestry $\left(X_{3}\right)$, fishing $\left(X_{4}\right)$ and total GDP (Y) were collected for analysis. The period covered is 33 years from 1981to 2013. Below is the contribution of agricultural sector to total GDP for the period of 32 years.

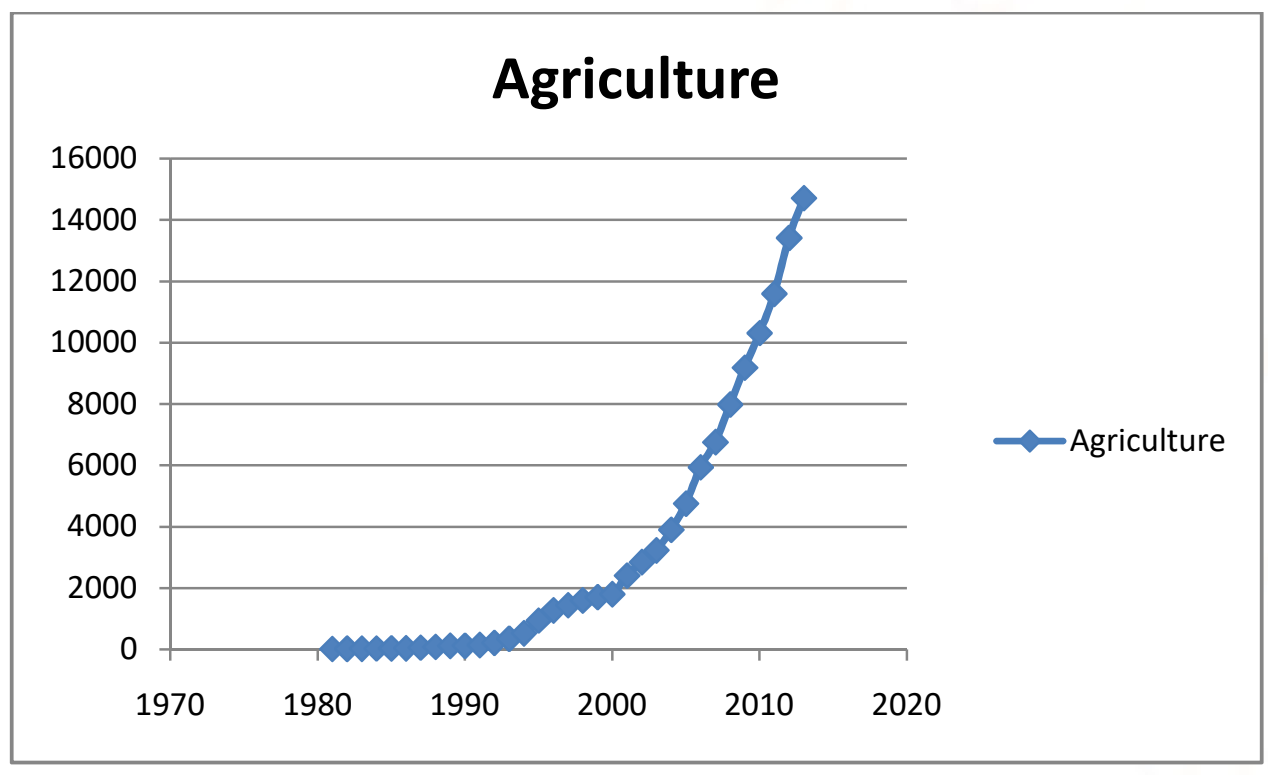

Fig. 2: Annual GDP from Agriculture from 1981 to 2013 

www.ijtsrd.com

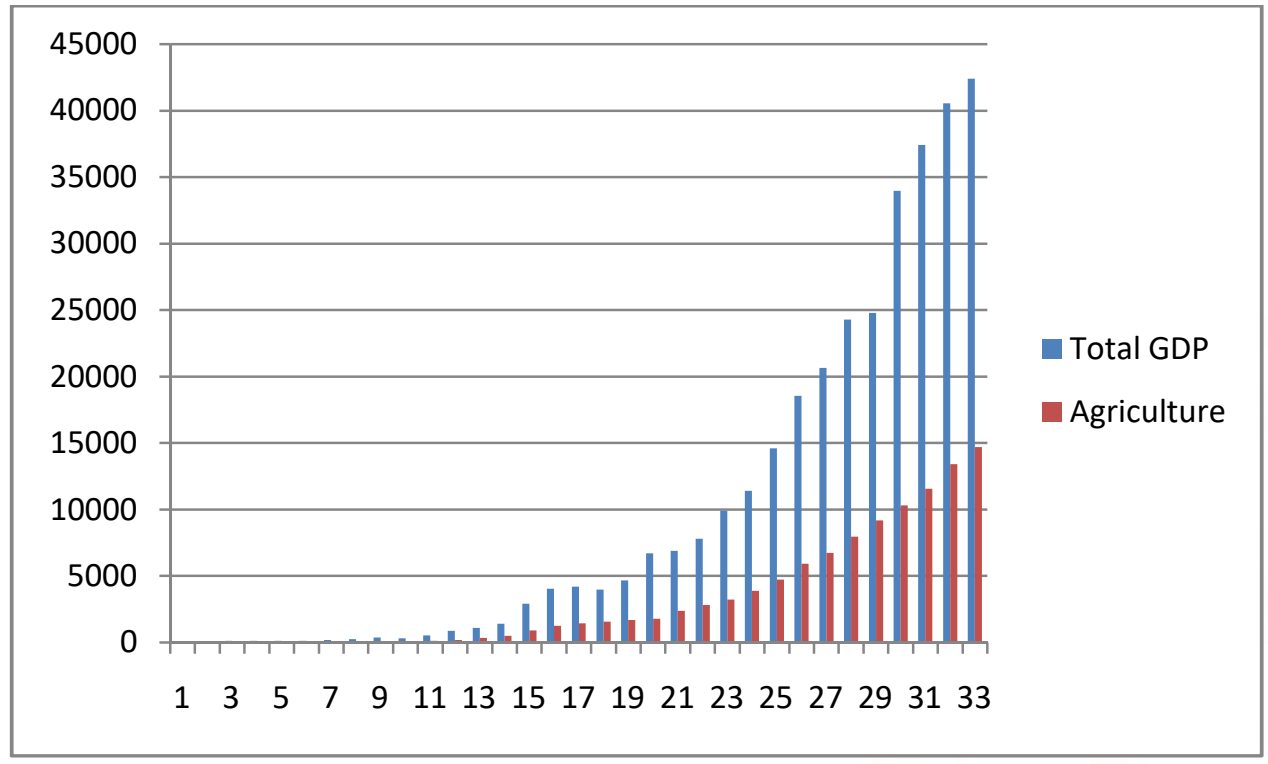

Fig. 3: Bar chart of Total GDP and GDP from Agriculture

The graphical display of four quarters of 2013 data is presented in figure 3 below to give us an overview of each sub-sectors contribution to the entire GDP from Agriculture.

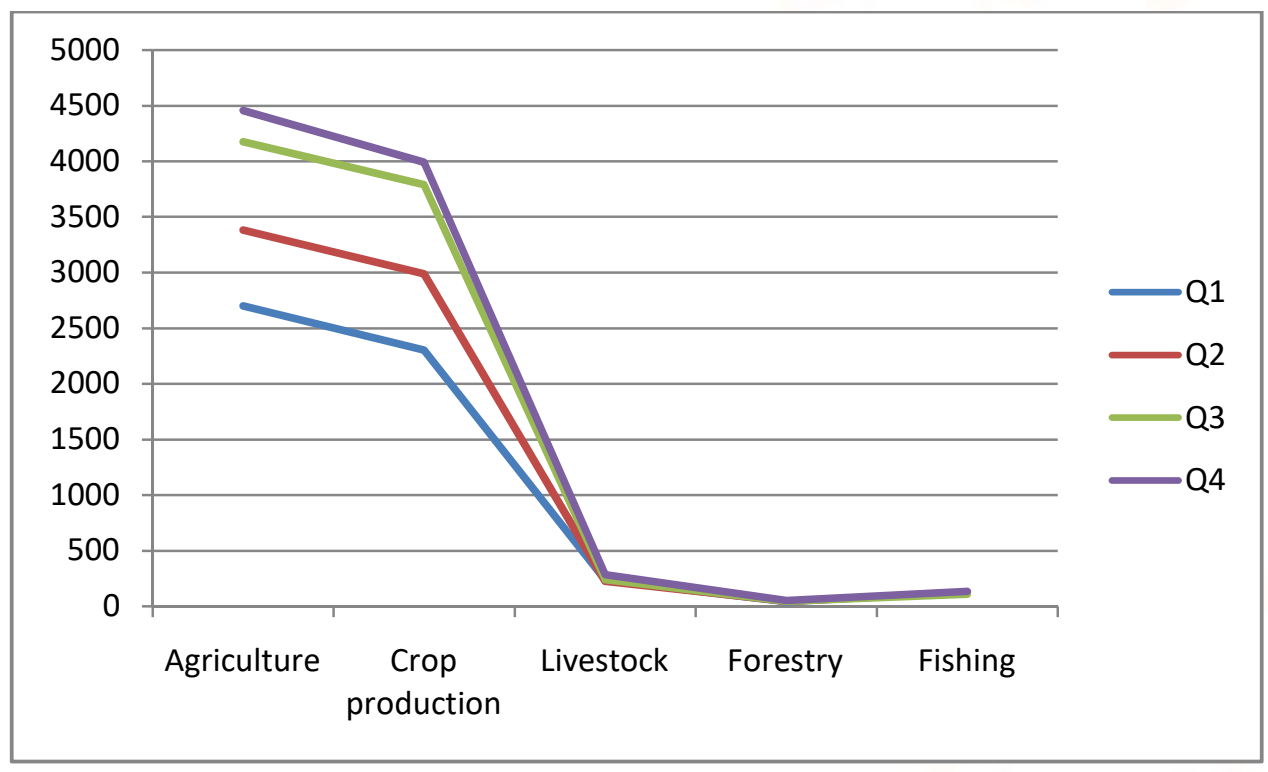

Fig. 2: Quarterly Gross Domestic Product at Current Basic Price (N'Billion) for 2013

To determine the suitable model we are going to build for our data, the correlation matrix for the data was computed to check for possible correlates. The correlation matrix for the data is shown in Appendix A below.

\section{Methodology}

\subsection{Collinearity}

Collinearity is the existence of near perfect linear relationship among the explanatory variables of multiple regressions. Suppose we have the sum of four explanatory variables $X_{1}+X_{2}+X_{3}+X_{4}$ as in the case of this our study as a component of a whole, then there is tendency that the variables will be linearly related to one another, thereby creating inaccurate estimate of the regression coefficients. Observe from the correlation matrix in Appendix A that there exists perfect linear relationship between crop production and livestock and near perfect relationship among other variables. This is a case of data that is suffering from multicollinearity. When the 
multicollinearity occurs, least square estimates are unbiased, but their variances are large so they may be misleading.

From Appendix B, the OLS regression of the data produces estimates with very high variance inflation factor. This problem made us to compute the principal component regression PCR which is a biased estimation method often used in overcoming the multicollinearity problem. PCR can lead to efficient prediction of the outcome based on the assumed model (GlitchdataWiki 2016). It tends to perform well when the first principal components are enough to explain most of the variation in the predictors. A significant benefit of PCR is that by using the principal components, if there is some degree of multicollinearity between the variables in your data sets, this procedure should be able to avoid this problem since performing PCA on the raw data produces linear combinations of the predictor that are uncorrelated (Michy 2016). The PCR result of the data in Appendix $\mathrm{C}$ was obtained from regressing first principal component that accounted for $99.9 \%$ of the total variability in the original data on the response variable. The result produced a model that can efficiently be used in predicting the outcome. The result has the coefficient that is highly significant with a very low VIF, but with a higher standard error and lesser adjusted R-square than that of OLS. This led to computation of another biased regression estimation method for solving the problem of multicollinearity known as ridge regression.

\subsection{Ridge Regression}

Ridge regression is a biased regression technique used in analyzing multiple regression data when the explanatory variables are linearly correlated. When multicollinearity occurs, ordinary least square regression (OLS) may produce estimates with inflated variances thus giving us the model that are not reliable. Ridge regression is like least square but it shrinks the estimated coefficient towards zero by adding a small constant term $k \geq 0$ to the diagonal element of the $X^{\prime} X$ before finding it inverse as in the case of OLS. Given a response vector $y \in R^{n}$ and a predictor matrix $X \in R^{n \times p}$ the ridge regression estimate $\hat{\beta}^{\text {ridge }}$ is defined as the value of $\beta$ that minimizes the penalized sum of squares $\sum_{i}\left(y_{i}-\right.$ $\left.X^{\prime} \beta\right)^{2}+k \sum_{j=1}^{p} \beta_{j}^{2}$, that is,

$$
\begin{aligned}
\hat{\beta}^{\text {ridge }} & =\underset{\beta \in R^{p}}{\operatorname{argmin}} \sum_{i=1}^{n}\left(y_{i}-x^{\prime} \beta\right)^{2}+k \sum_{i=1}^{p} \beta_{j}^{2} \\
& =\underset{\beta \in R^{p}}{\operatorname{argmin}}\left\|y-X^{\prime} \beta\right\|_{2}^{2}+k\|\beta\|_{2}^{2}
\end{aligned}
$$

The constant $k \geq 0$ (a pre-chosen constant) is a tuning parameter which controls the strength of the penalty term $k \sum_{i=1}^{p} \beta_{j}^{2}$. Applying the ridge regression penalty has the effect of shrinking the estimates toward zero; introducing bias but reducing the variance of the estimates. Equation (1) is equivalent to minimization of $\sum_{i=1}^{n}\left(y_{i}-\sum_{j=1}^{p} x_{i j} \beta_{j}\right)^{2}$ subject to $\sum_{j=1}^{p} \beta_{j}^{2}<k$, that is, constraining the sum of the squared coefficients. Note that

- When $k=0$, we get the linear regression estimate

- When $k=\infty$, we get $\hat{\beta}^{\text {ridge }}=0$

- For $k$ in between, we are balancing two ideas: fitting a linear model of $\mathrm{y}$ on $\mathrm{x}$, and shrinking the coefficients.

Therefore the ridge regression coefficient can be obtained thus,

$$
\hat{\beta}^{\text {ridge }}=\left(X^{\prime} X+k I_{p}\right)^{-1} X^{\prime} Y
$$

The variance of the ridge regression estimates is

$$
\operatorname{var}\left(\hat{\beta}^{\text {ridge }}\right)=\sigma^{2}\left(X^{\prime} X+k I_{p}\right)^{-1} X^{\prime} X\left(X^{\prime} X+k I_{p}\right)^{-1}
$$

The bias of the ridge regression estimates is

$$
\begin{aligned}
& \operatorname{Bias}\left(\hat{\beta}^{\text {ridge }}\right) \\
& =-k\left(X^{\prime} X\right. \\
& \left.+k I_{p}\right)^{-1} \beta
\end{aligned}
$$

The total variance $\sum_{j} \operatorname{var}\left(\hat{\beta}_{j}^{\text {ridge }}{ }_{j}\right)$ is a monotone decreasing function, while the total square bias $\sum_{j} \operatorname{Bias}^{2}\left(\hat{\beta}_{j}^{\text {ridge }}\right)$ is a monotone increasing sequence with respect to $k$.

The least eigenvalue of the explanatory variables is chosen to be the value of $k$ in this study. This value gives better result than other pre-assigned values as suggested by Okeke and Okeke (2015). From Appendix $\mathrm{C}$ we have this value to be 0.0001 . 


\section{Result and Discussion}

Four different regression estimation methods were computed in this work due to nature of our data. This is to help us come up with a best model form predicting the GDP of Nigeria.

\subsection{Result from OLS}

From the analysis we have that the OLS estimated regression model of the variable $\mathrm{Y}$ is

$$
\begin{array}{r}
y=-212.745+2.8386 X_{1}+21.8189 X_{2} \\
+180.317 X_{3}-94.9677 X_{4}
\end{array}
$$

The adjusted coefficient of determination was obtained to be 0.9943 , which indicates that the model is adequate in predicting the dependent variable. The standard error of the estimate is 987.792

To determine the power of each explanatory variable in explaining the dependent variable, we standardized the coefficients and have the model with the standardized coefficients to be

$$
\begin{gathered}
y=0.833 x_{1}+0.466 x_{2}+0.717 x_{3} \\
-1.019 x_{4}
\end{gathered}
$$

The model (4) showed that crop production, Forestry and livestock production have positive influence on the total GDP of Nigeria. Fisheries have negative influence on GDP. This result goes a long way to say that much work is needed to be done in our fish production in order to improve Nigerian economy. The highest value of the coefficient of crop production indicates that among the four agricultural sub-sectors that crop production has strong influence in her GDP. The very high values of VIF of the coefficients gave rise to PCR.

\subsection{Results from PCR}

The PCR model of the data which was computed using the first principal component was obtained to be

$$
y_{P C}=-1.0+6.05 P C
$$

This model has adjusted R-square of 0.994 which is a little lesser than that of OLS, but with very small VIF of 1 . The standard error of the model is 997.674 and this is higher than that of OLS which is obtained to be 987.792. The calculated P-value of the PC is 0.000 which indicate that the linear combination (PC) is highly significant in predicting $\mathrm{y}$. The first principal component used is

$$
\begin{gathered}
P C=0.5000 x_{1}+0.5000 x_{2}+0.5000 x_{3} \\
+0.5000 x_{4}
\end{gathered}
$$

\subsection{Result from Ridge Regression}

Different values of the tuning parameter $\mathrm{k}$ were considered in our effort to build a model that will give us better prediction. The values were: the least, second to the least, the median and highest eigenvalues of the explanatory variables. The least eigenvalu value was finally chosen because it provided the model with highest adjusted $R^{2}$ (which is 99.43) than the others with smallest standard error of the estimate $(\mathrm{s}=987.7905)$. The ridge regression model

$$
\begin{gathered}
y_{\text {ridge }}=-212.7437+2.8386 x_{1}+21.8188 x_{2} \\
+180.3174 x_{3}-94.9674 x_{4}
\end{gathered}
$$

The ridge regression model with the standardized coefficients is

$$
\begin{gathered}
y_{\text {ridge }}=0.8332 x_{1}+0.4602 x_{2}+0.7118 x_{3} \\
-1.0074 x_{4}
\end{gathered}
$$

Observe that the result of ridge regression is almost exactly that of OLS but with little variation on the standard error of the estimate and shrink on the values of the regression coefficients.

\subsection{Result from Stepwise Regression}

The stepwise regression gave the estimated model of the variable $Y$ to be

$$
y_{S W}=-7.128+3.397 x_{1}
$$

The model has adjusted R-squared value of 0.994 . The VIF of the crop production which is the only variable it retained is 1 . The excluded factors are livestock, forestry, and fishery with VIFs of 1849.138, 309.069 , and 769.811 respectively. The standard error of the estimate is obtained to be 995.2167 .

\section{REFERENCES}

1) Central Bank of Nigeria (2014). Central Bank of Nigeria Statistical Bulletin, vol. 12, December 2014

2) Ezeokoli, P. I. (2011). A regression analysis on impact of Agriculture on Nigeria economy, 
Unpublished B. Sc project, Nnamdi Azikiwe University Awka

3) Glitchdat Wiki (2016). Principal component regression,

http://wiki.glitchdata.com/index.php?title=Princip al_Component_Regression

4) Gollin, D., Parente, S. L. and Rogerson, R.(2004). Farm work, home work and international productivity differences, Review of Economic Dynamics, 7(4): 827-850

5) Izuchukwu, O. (2011). Analysis of the contribution of agricultural sector on the Nigeria economic development, Research Gate

6) Michy, A. (2016). Performing principal component regression (PCR) in R, MilanoR, Italy, http://www.milanor.net/blog/performingprincipal-components-regression-pcr-in-r/

7) Noko, E. J. (2017). Impact of agricultural sector on Nigeria economic growth, Edu cac Info, www.educacinfo.com/agricultural-sector-nigeriaecomomic-growth/

8) Setoglu, K., Ugural, S. and Bekun F. V (2013). The contribution of agricultural sector on the
Nigeria economic development, International Journal of Economics and Finance Issues, 7(1), 547-552,

https://www.econjournals.com/index.php/ijefi/arti cle/viewFile/3941/pdf

9) Ukeje, E. U. (1999). The role of agricultural sector as an accelerator for economic growth in Nigeria economy, www.projectfaculty.com/resources/resourceeconomics-ecn $433 . \mathrm{htm}$

10) Ukeje, R. O. (2003). Macroeconomics: An introduction, Davidson publications, Port Harcourt

11) Uzonwanne, J. (2017). CBN approves \#75 billion loans for agricultural lending in states, Abuja, Premium Times, Wednesday May 10, www.premiumtimesng.com/.../5486cbn_approves_n75billion_loan_for_agricultural...

12) Wikipedia (2017). https://en.wikipedia.org/wiki/Agriculture_in_Nige ria

\section{Appendix A}

\begin{tabular}{|c|c|c|c|c|c|c|}
\hline \multicolumn{2}{|c|}{ Correlations } & $\begin{array}{c}\text { Crop } \\
\text { production }\end{array}$ & $\begin{array}{c}\text { Livest } \\
\text { ock }\end{array}$ & $\begin{array}{c}\text { Forest } \\
\text { ry }\end{array}$ & $\begin{array}{c}\text { Fisher } \\
\text { y }\end{array}$ & GDP1 \\
\hline \multirow{4}{*}{$\begin{array}{c}\text { Crop } \\
\text { production }\end{array}$} & $\begin{array}{c}\text { Pearson } \\
\text { Correlation }\end{array}$ & 1 & $1.000^{* *}$ & $.998^{* *}$ & $.999^{* *}$ & $.997^{* *}$ \\
\cline { 2 - 7 } & Sig. (2-tailed) & & .000 & .000 & .000 & .000 \\
\cline { 2 - 7 } & $\mathrm{N}$ & 33 & 33 & 33 & 33 & 33 \\
\hline \multirow{4}{*}{ Livestock } & $\begin{array}{c}\text { Pearson } \\
\text { Correlation }\end{array}$ & $1.000^{* *}$ & 1 & $.998^{* *}$ & $.999^{* *}$ & $.997^{* *}$ \\
\cline { 2 - 7 } & Sig. (2-tailed) & .000 & & .000 & .000 & .000 \\
\cline { 2 - 7 } & $\mathrm{N}$ & 33 & 33 & 33 & 33 & 33 \\
\hline \multirow{4}{*}{ Fisherestry } & $\begin{array}{c}\text { Pearson } \\
\text { Correlation }\end{array}$ & $.998^{* *}$ & $.998^{* *}$ & 1 & $.999^{* *}$ & $.996^{* *}$ \\
\cline { 2 - 7 } & Sig. (2-tailed) & .000 & .000 & & .000 & .000 \\
\cline { 2 - 7 } & $\mathrm{N}$ & 33 & 33 & 33 & 33 & 33 \\
\hline & $\begin{array}{c}\text { Pearson } \\
\text { Correlation }\end{array}$ & $.999^{* *}$ & $.999^{* *}$ & $.999^{* *}$ & 1 & $.996^{* *}$ \\
\cline { 2 - 7 } & Sig. (2-tailed) & .000 & .000 & .000 & & .000 \\
\cline { 2 - 7 } & $\mathrm{N}$ & 33 & 33 & 33 & 33 & 33 \\
\hline \multirow{2}{*}{ GDP1 } & Pearson & $.997^{* *}$ & $.997^{* *}$ & $.996^{* *}$ & $.996^{* *}$ & 1 \\
\hline
\end{tabular}


International Journal of Trend in Scientific Research and Development, Volume 1(4), ISSN: 2456-6470 www.ijtsrd.com

\begin{tabular}{|l|l|r|r|r|r|r|}
\hline & Correlation & & & & & \\
\cline { 2 - 7 } & Sig. (2-tailed) & .000 & .000 & .000 & .000 & \\
\cline { 2 - 7 } & $\mathrm{N}$ & 33 & 33 & 33 & 33 & 33 \\
\hline
\end{tabular}

\section{Appendix B}

\begin{tabular}{|c|c|c|c|c|c|c|c|c|c|c|c|}
\hline \multicolumn{12}{|c|}{ Coefficients $^{\mathrm{a}}$} \\
\hline & \multirow{2}{*}{ Model } & \multicolumn{2}{|c|}{$\begin{array}{c}\text { Unstandardized } \\
\text { Coefficients }\end{array}$} & \multirow{2}{*}{$\begin{array}{c}\begin{array}{c}\text { Standar } \\
\text { dized } \\
\text { Coeffici } \\
\text { ents }\end{array} \\
\text { Beta }\end{array}$} & \multirow{2}{*}{$\mathbf{t}$} & \multirow{2}{*}{ Sig. } & \multicolumn{3}{|c|}{ Correlations } & \multicolumn{2}{|c|}{ Collinearity Statistics } \\
\hline & & B & $\begin{array}{l}\text { Std. } \\
\text { Error }\end{array}$ & & & & $\begin{array}{l}\text { Zero- } \\
\text { order }\end{array}$ & $\begin{array}{l}\text { Par } \\
\text { tial }\end{array}$ & Part & Tolerance & VIF \\
\hline \multirow{5}{*}{1} & (Constant) & -212.745 & 257.615 & & -.826 & .416 & & & & & \\
\hline & $\begin{array}{c}\text { Crop } \\
\text { production }\end{array}$ & 2.839 & 2.422 & .833 & 1.172 & .251 & .997 & .216 & .016 & .000 & 2820.006 \\
\hline & Livestock & 21.819 & 35.520 & .466 & .614 & .544 & .997 & .115 & .008 & .000 & 3209.256 \\
\hline & Forestry & 180.317 & 104.647 & .717 & 1.723 & .096 & .996 & .310 & .023 & .001 & 966.184 \\
\hline & Fishery & -94.968 & 61.473 & -1.019 & -1.545 & .134 & .996 & $\begin{array}{c}- \\
.280\end{array}$ & $\begin{array}{c}- \\
.021\end{array}$ & .000 & 2425.124 \\
\hline
\end{tabular}

General Regression Analysis: Total GDP versus crop product, Livestock, ...

Regression Equation

Total GDP $=-212.745+2.83862$ crop production +21.8189 Livestock +180.317

Forestry - 94.9677 Fishery

Coefficients

$\begin{array}{lrrrr}\text { Term } & \text { Coef } & \text { SE Coef } & \text { T } & \text { P } \\ \text { Constant } & -212.745 & 257.615 & -0.82583 & 0.416 \\ \text { Crop production } & 2.839 & 2.422 & 1.17179 & 0.251 \\ \text { Livestock } & 21.819 & 35.520 & 0.61427 & 0.544 \\ \text { Forestry } & 180.317 & 104.647 & 1.72310 & 0.096 \\ \text { Fishery } & -94.968 & 61.473 & -1.54486 & 0.134\end{array}$

Summary of Model

$\begin{array}{lll}S=987.792 & R-S q=99.50 \% & R-S q(\operatorname{adj})=99.43 \% \\ \text { PRESS }=116317651 & R-S q(\text { pred })=97.86 \% & \end{array}$

Analysis of Variance

Regression

$\begin{array}{rrrrrrr}\text { DF } & \text { Seq SS } & \text { Adj SS } & \text { Adj MS } & \text { F } & P \\ 4 & 5413288403 & 5413288403 & 1353322101 & 1386.98 & 0.000000\end{array}$ 
International Journal of Trend in Scientific Research and Development, Volume 1(4), ISSN: 2456-6470 www.ijtsrd.com

\begin{tabular}{|c|c|c|c|c|c|c|}
\hline crop production & 1 & 5409904756 & 1339775 & 1339775 & 1.37 & 0.251155 \\
\hline Livestock & 1 & 425775 & 368175 & 368175 & 0.38 & 0.543994 \\
\hline Forestry & 1 & 629191 & 2897030 & 2897030 & 2.97 & 0.095898 \\
\hline Fishery & 1 & 2328682 & 2328682 & 2328682 & 2.39 & 0.133608 \\
\hline Error & 28 & 27320512 & 27320512 & 975733 & & \\
\hline Total & 32 & 5440608915 & & & & \\
\hline
\end{tabular}

Fits and Diagnostics for Unusual Observations
$\begin{array}{rrrrrrrr}\text { Obs } & \text { Total GDP } & \text { Fit } & \text { SE Fit } & \text { Residual } & \text { St Resid } & & \\ 29 & 24794.2 & 28224.1 & 486.235 & -3429.83 & -3.98896 & \mathrm{R} & \\ 30 & 33984.8 & 31588.9 & 425.350 & 2395.84 & 2.68736 & \mathrm{R} & \\ 31 & 37409.9 & 35387.7 & 469.032 & 2022.15 & 2.32610 & \mathrm{R} & \\ 33 & 42396.8 & 43640.6 & 913.823 & -1243.88 & -3.31660 & \mathrm{R} & \mathrm{X}\end{array}$

\section{Appendix C}

\section{Principal Component Analysis: crop production, Livestock, Forestry, Fishery}

$\begin{array}{lrrrr}\text { Eigenanalysis of the Correlation Matrix } \\ \text { Eigenvalue } & 3.9969 & 0.0025 & 0.0005 & 0.0001 \\ \text { Proportion } & 0.999 & 0.001 & 0.000 & 0.000 \\ \text { Cumulative } & 0.999 & 1.000 & 1.000 & 1.000\end{array}$

$\begin{array}{lrrrr}\text { Variable } & \text { PC1 } & \text { PC2 } & \text { PC3 } & \text { PC4 } \\ \text { Crop production } & 0.500 & 0.333 & -0.585 & 0.544 \\ \text { Livestock } & 0.500 & 0.537 & 0.109 & -0.671 \\ \text { Forestry } & 0.500 & -0.768 & -0.278 & -0.288 \\ \text { Fishery } & 0.500 & -0.102 & 0.754 & 0.414\end{array}$

